\title{
Geochemical constraints on the petrogenesis of high-Mg basaltic andesites from the Northern Taiwan Volcanic Zone
}

\author{
Kuo-Lung Wang ${ }^{\mathrm{a}, *}$, Sun-Lin Chung ${ }^{\mathrm{a}}$, Chang-Hwa Chen ${ }^{\mathrm{b}}$, Cheng-Hong Chen ${ }^{\mathrm{a}}$ \\ a Department of Geosciences, National Taiwan University, 245 Choushan Road, Taipei, Taiwan \\ ${ }^{\mathrm{b}}$ Institute of Earth Sciences, Academia Sinica, P.O. Box 1-55, Nankang, Taipei, Taiwan
}

Accepted 1 June 2001

\begin{abstract}
The Northern Taiwan Volcanic Zone (NTVZ) is a Late Pliocene-Quaternary volcanic field that occurred as a result of extensional collapse of the northern Taiwan mountain belt. We report here mineral compositions, major and trace element and $\mathrm{Sr} / \mathrm{Nd}$ isotope data of high-Mg basaltic andesites from the Mienhuayu, a volcanic islet formed at $\sim 2.6 \mathrm{Ma}$ in the central part of the NTVZ. The rocks are hypocrystalline, showing porphyritic texture with Mg-rich olivine $($ Fo $\approx 81-80)$, bronzite $(\mathrm{En} \approx 82-79)$ and plagioclase $(\mathrm{An} \approx 66-58)$ as major phenocryst phases. They have uniform whole-rock compositions, marked by high magnesium $(\mathrm{MgO} \approx 5.9-8.1 \mathrm{wt} . \%, \mathrm{Mg}$ value $\approx 0.6)$ relative to accompanying silica contents $\left(\mathrm{SiO}_{2} \approx 52.8-54.5\right.$ wt.\% $)$. The high-Mg basaltic andesites contain the highest $\mathrm{TiO}_{2}(\sim 1.5$ wt.\% $)$ and lowest $\mathrm{K}_{2} \mathrm{O}(\sim 0.4$ wt.\%) among the NTVZ volcanic rocks. In the incompatible element variation diagram, these Mienhuayu magmas exhibit mild enrichments in large ion lithophile (LILE) and light rare earth elements (LREE), coupled with an apparent Pb-positive spike. They do not display depletions in high field strength elements (HFSE), a feature observed universally in the other NTVZ volcanics. The high-Mg basaltic andesites have rather unradiogenic $\mathrm{Nd}(\varepsilon \mathrm{Nd} \approx+5.1-7.2)$ but apparently elevated $\mathrm{Sr}\left({ }^{87} \mathrm{Sr} /{ }^{86} \mathrm{Sr} \approx 0.70435-0.70543\right.$; leached values $)$ isotope ratios. Their overall geochemical and isotopic characteristics are similar to mid-Miocene ( $\sim 13 \mathrm{Ma})$ high-Mg andesites from the Iriomote-jima, southern Ryukyus, Japan. Despite these magmas have lower LILE and LREE enrichments and $\mathrm{Pb}$ positive spike, their "intraplate-type" incompatible element variation patterns are comparable to those of extension-induced Miocene intraplate basalts emplaced in the Taiwan-Fujian region. Therefore, we interpret the Mienhuayu magmas as silica-saturated melts derived from decompression melting of the ascended asthenosphere that had been subtly affected by the adjacent Ryukyu subduction zone processes. This interpretation is consistent with the notion that in the northern Taiwan mountain belt post-orogenic lithospheric extension started in Plio-Pleistocene time. (C) 2002 Elsevier Science B.V. All rights reserved.
\end{abstract}

Keywords: High-Mg basaltic andesite; Geochemistry; Taiwan; Ryukyu subduction; Post-orogenic magmatism

\footnotetext{
* Corresponding author. Present address: GEMOC, Department of Earth and Planetary Sciences, Macquarie University, Sydney, NSW 2109, Australia. Tel.: +61-2-9850-9673; fax: +886-2-23636095 .

E-mail address: Kwang@els.mq.edu.au (K.-L. Wang).
}

\section{Introduction}

High-Mg andesites, i.e. boninite and sanukite, represent a group of intermediate rocks that have been extensively studied for their unique petrological and geochemical features and geodynamic significance (Crawford et al., 1989; Tatsumi and Maruyama, 
1989). These rocks, generally defined as having volatile-free recalculated compositions of $\mathrm{SiO}_{2}>53$ wt. $\%$ and $\mathrm{MgO}>8 \mathrm{wt} \%$, occur exclusively in the fore-arc region of certain convergent margins. Their mantle sources are widely accepted to be considerably more refractory than those of mid-ocean ridge basalts (MORB) and typical arc magmas. Therefore, two important "ingredients" required for high-Mg andesite production would be: (1) a supply of hydrous fluids into the refractory mantle source to lower its solidus temperature and permit partial melting, and (2) a mechanism capable of producing and then maintaining a very high geotherm in the mantle wedge (cf. Crawford et al., 1989 for review). The latter often involves formation of the back-arc basin. Investigations of high- $\mathrm{Mg}$ andesites, consequently, can provide pivotal information for understanding mantle dynamics and magma generation beneath the convergent margins in not only the fore-arc but also back-arc regions.
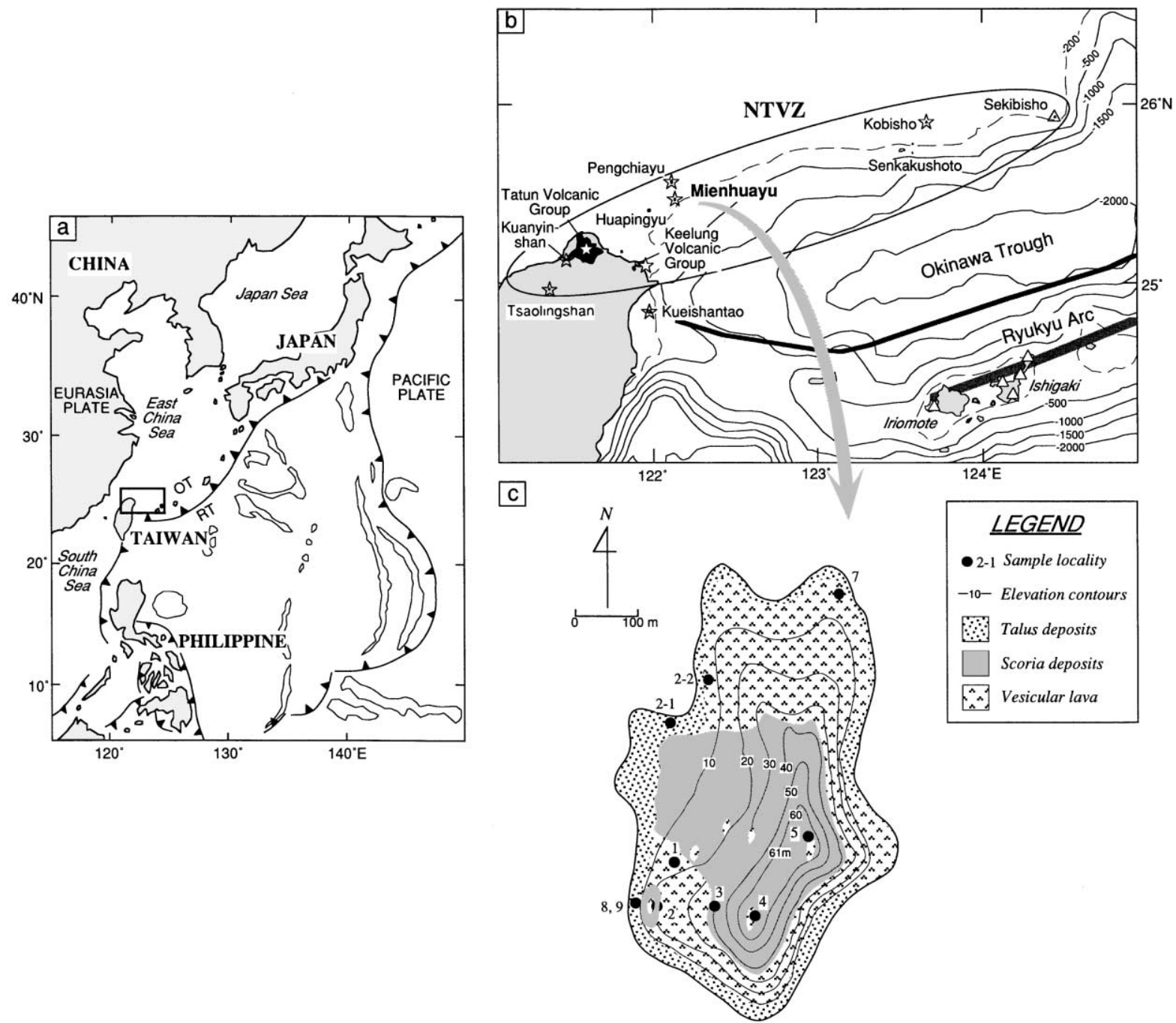

Fig. 1. (a) Tectonic framework in the vicinity of Taiwan. OT: Okinawa Trough, RT: Ryukyu Trench. (b) Bathymetric map showing the location of Mienhuayu in the Northern Taiwan Volcanic Zone (NTVZ). Open triangles and stars indicate Tertiary and Quaternary volcanoes, respectively. Thick line indicates the surface projection of the $100-\mathrm{km}$ deep Wadati-Benioff zone of the subducting Philippine Sea plate (Sibuet et al., 1998). (c) Simplified geologic map showing major volcanic units on the Mienhuayu islet. 
Recently, Shinjo (1999) reported new geochemical data for high-Mg andesites from several localities in the Ryukyu arc-Okinawa Trough back-arc basin system, which shed light on the nature of the mantle wedge under the Ryukyu subduction zone as well as the tectonomagmatic evolution of the TaiwanOkinawa Trough areas (Fig. 1). In contrast to high$\mathrm{Mg}$ andesites from the central Ryukyu and other fore-arc regions worldwide, mid-Miocene $(\sim 13 \mathrm{Ma})$ high-Mg andesites from the Iriomote-jima, southern Ryukyus (Fig. 1b) show ocean island basalt (OIB) geochemical and isotopic affinities that are comparable to Miocene intraplate basalts emplaced around the Taiwan-Fujian region (Chung et al., 1994, 1995). This new finding led Shinjo (1999) to conclude that at that time Ryukyu subduction did not exist in the Iriomote area and the westernmost part of the southern Ryukyu arc-trench system was established only after the collision between the northern Luzon arc and the Asian continent near Taiwan. In this paper, we report the occurrence of petrochemically similar but younger $(\sim 2.6 \mathrm{Ma})$ high-Mg basaltic andesites from the NTVZ, located $\sim 150 \mathrm{~km}$ behind the present-day southern Ryukyu arc-trench system (Fig. 1). The main objectives of our study include: (1) to document the petrological and geochemical features of these magmas; (2) to discuss petrogenetic processes involved in magma evolution; and (3) to better understand the geodynamic implications of development of the NTVZ and the particular collision/extension/subduction tectonic setting in the Taiwan-Okinawa-Ryukyu region.

\section{Geologic background of the NTVZ}

The island of Taiwan is an active mountain belt created by oblique collision of the northern Luzon arc with the southeastern Asian continent starting $\sim 12 \mathrm{Ma}$ (cf. Teng, 1990 for review). In central and southern Taiwan the tectonism reflects the ongoing collision, but in northern Taiwan extensional collapse began around Plio-Pleistocene time (Teng, 1996). Consequently, a series of onshore and offshore volcanoes erupted during the Late Pliocene and Quaternary ( 2.8 Ma-recent), which altogether comprise the NTVZ (Fig. 1b). The NTVZ has been regarded as the westernmost part of the Ryukyu volcanic arc (e.g., Chen, 1990; Teng, 1996). Such a conventional view was first questioned by Chen (1997) who suggested an extension-related instead of a subduction-related setting for magma generation. To accommodate available geochemical, geophysical and geologic evidence, Wang et al. (1999) proposed a new model that the NTVZ resulted from post-collisional lithospheric extension owing to the collapse of the northern Taiwan mountain belt. This extension could, furthermore, have played a key role in the re-opening of the middle Okinawa Trough, and give way to its rapid southwestward propagation with associated development of the westernmost part of the southern Ryukyu arc-trench system. These tectonomagmatic processes may eventually have led to the present-day collision/extension/subduction context in the region of northern Taiwan (Wang et al., 1999).

Wang et al. (1999) also noted that the NTVZ shows a spatial geochemical variation. From the northeast to the southwest, the magmas produced vary generally from low-K to calc-alkaline and then shoshonitic compositions. Most NTVZ volcanics have arc-like geochemical features, i.e., with significant enrichments in LILE and $\mathrm{Pb}$ and depletion in HFSE. This indicates that their mantle source regions must have been modified by processes associated with adjacent Ryukyu subduction zone. Volcanic rocks from two locations are particularly distinctive in their whole-rock chemistry. These are: (1) high-Mg potassic absarokites $\left(\mathrm{SiO}_{2} \approx 48\right.$ wt. $\% ; \mathrm{MgO} \approx 15$ wt. $\% ; \mathrm{K}_{2} \mathrm{O} \approx 5$ wt.\%) from the Tsaolingshan in the westernmost part of the NTVZ (Chung et al., 2001b); and (2) high-Mg basaltic andesites from the Mienhuayu in the central NTVZ (see below).

\section{Field occurrence and ages}

The Mienhuayu islet consists mainly of mafic lava flows and subordinate scoria deposits (Fig. 1c). Two types of lava, $a^{\prime}$ a and pahoehoe, were identified and both show oxidizing features indicative of subaerial effusion of basaltic magmas (Rowland and Walker, 1990; Paulick and Franz, 1997; Self et al., 1998). Detailed description for the field relations has been published separately (Wang et al., 2000). Juang (1993) reported K-Ar dates suggesting that the vol- 
canism occurred during 0.53-0.44 Ma. However, our recent ${ }^{40} \mathrm{Ar} /{ }^{39} \mathrm{Ar}$ dating result reveals a significantly older age ( $2.6 \mathrm{Ma}$; Wang et al., 2000). Therefore, we suggest that the Mienhuayu volcanic eruptions started around $2.6 \mathrm{Ma}$, and lasted in to the Quaternary. In this sense, onset of Mienhuayu volcanism is broadly synchronous to that of the Tatun Volcanic Group ( 2.8 Ma; Wang and Chen, 1990) on Taiwan and Sekibisho volcanism to the north of the Okinawa Trough (Fig. 1) ( $\sim 2.6 \mathrm{Ma}$; Shinjo et al., 1991), which represent the earliest phase of NTVZ activity, starting around the Plio-Pleistocene boundary.

\section{Petrography and mineral chemistry}

All volcanic rocks from Mienhuayu show hypocrystalline textures. They contain micro-phenocrysts in an aphanitic matrix with abundant vesicles. Microscopically, they show porphyritic textures (Fig. 2) with euhedral olivine $(0.25-2 \mathrm{~mm}$ in size) as the most abundant phenocryst, plus additional orthopyroxene and plagioclase. Clinopyroxene was not recorded as a phenocryst. Groundmass, which makes up $>70 \%$ of the volume, consists mostly of plagioclase, with subordinate olivine, orthopyroxene and iron oxides.

In Fig. 3, we show electron microprobe data (from Chen, 1990) for representative phenocryst

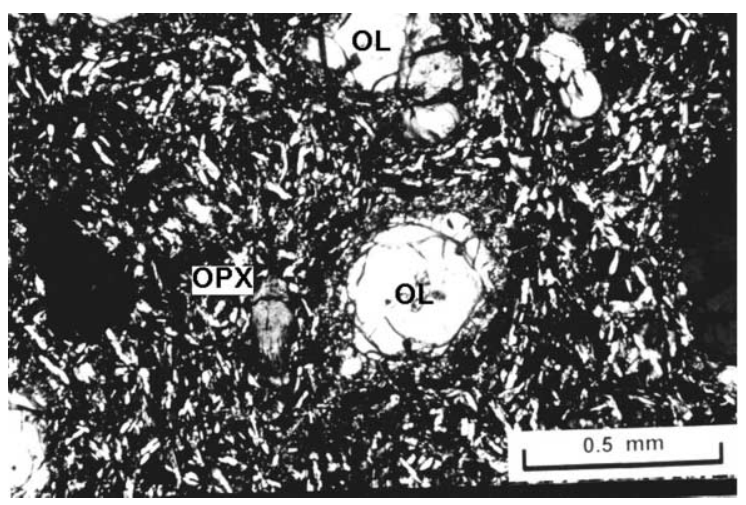

Fig. 2. Thin section photo showing porphyritic texture with glassy matrix of the Mienhuayu sample MHY-2-6. The most abundant phenocryst phase is euhedral olivine (OL). a
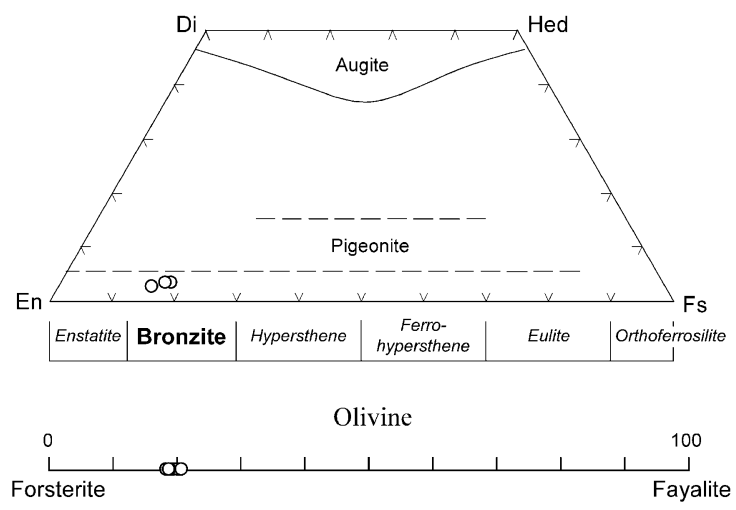

b

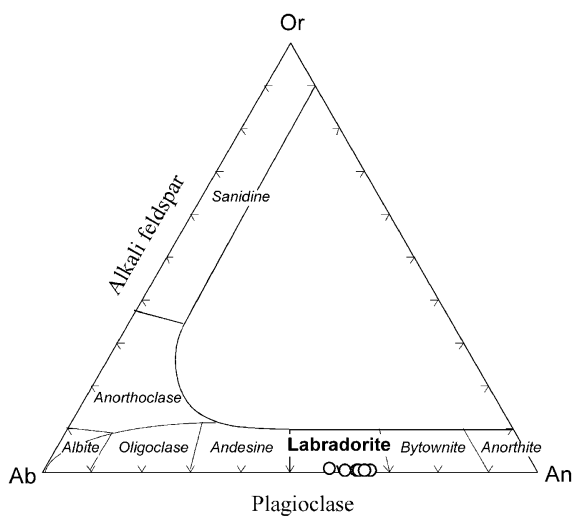

Fig. 3. Plots of mineral compositions for the Mienhuayu volcanic rocks. (a) Pyroxenes and olivines, which mark with high Fo contents up to 82. (b) Plagioclases. Data are from Chen (1990).

phases in the Mienhuayu volcanics, indicating their uniform and high-Mg compositions. Both olivine and orthopyroxene show restricted compositions and plagioclase ranges from An58 to An66.

\section{Samples and analytical methods}

Ten lava flow samples and one scoria (MHY-3) sample collected from Mienhuayu (Fig. 1c) were subjected to whole rock major and trace element, and $\mathrm{Sr} / \mathrm{Nd}$ isotope determinations. Powder samples were prepared using a jaw crusher and a corundum mill. 
Table 1

Chemical and isotopic composition of the Mienhuayu high-Mg basaltic andesites, off NE Taiwan

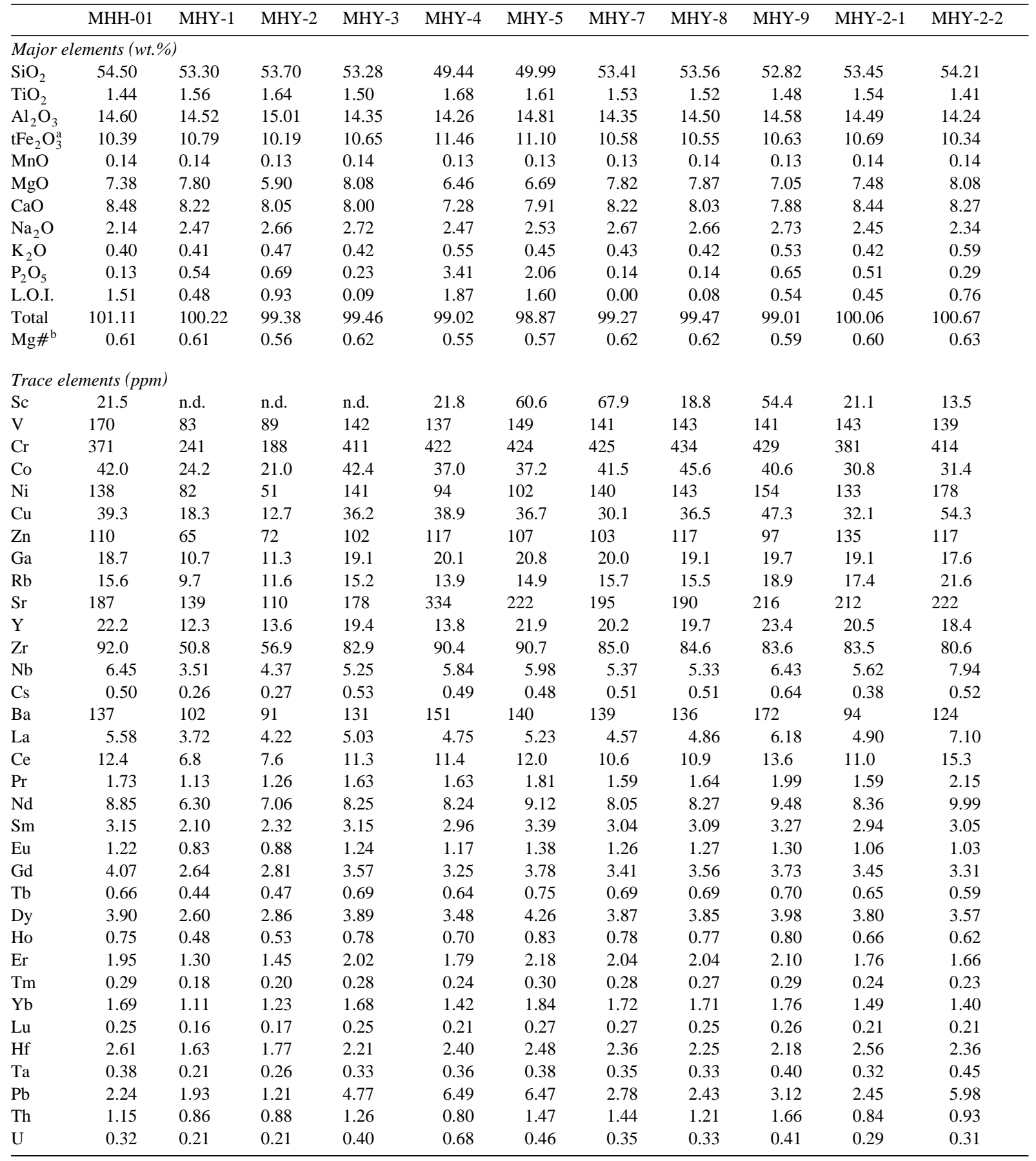


Table 1 (continued)

\begin{tabular}{llllllllllll}
\hline & MHH-01 & MHY-1 & MHY-2 & MHY-3 & MHY-4 & MHY-5 & MHY-7 & MHY-8 & MHY-9 & MHY-2-1 & MHY-2-2 \\
\hline${ }^{87} \mathrm{Sr} /{ }^{86} \mathrm{Sr}$ & 0.70461 & & 0.70453 & 0.70446 & 0.70722 & & 0.70438 & 0.70440 & 0.70447 & & \\
${ }^{87} \mathrm{Sr} /{ }^{86} \mathrm{Sr}^{\mathrm{c}}$ & & 0.70448 & & & 0.70543 & 0.70451 & 0.70435 & & & \\
${ }^{143} \mathrm{Nd} /{ }^{144} \mathrm{Nd}$ & 0.51298 & & 0.51301 & 0.51290 & 0.51294 & & 0.51299 & 0.51297 & 0.51293 & & \\
$\varepsilon \mathrm{Nd}^{\mathrm{d}}$ & 6.6 & & 7.2 & 5.1 & 5.9 & 6.8 & 6.4 & 5.6 & & \\
\hline
\end{tabular}

n.d.: Not determined.

${ }^{\mathrm{a}}$ Total iron.

${ }^{\mathrm{b}} \mathrm{Mg} \#=\mathrm{Mg}_{\mathrm{mol}}^{2+} /\left(\mathrm{Mg}_{\text {mol }}^{2+}+\mathrm{Fe}_{\mathrm{mol}}^{2+}\right)$.

${ }^{\mathrm{c}}$ Determined after acid leaching.

${ }^{\mathrm{d}}{ }_{\varepsilon \mathrm{Nd}}=\left[\left({ }^{143} \mathrm{Nd} /{ }^{144} \mathrm{Nd}\right)_{\text {sample }} /\left({ }^{143} \mathrm{Nd} /{ }^{144} \mathrm{Nd}\right)_{\mathrm{CHUR}}-1\right] \times 10^{4} ;\left({ }^{143} \mathrm{Nd} /{ }^{144} \mathrm{Nd}\right)_{\mathrm{CHUR}}=0.51264$.

Major element compositions were determined by X-ray fluorescence (XRF) using a Rigaku ${ }^{\circledR}$ RIX 2000 spectrometer at Department of Geosciences, National Taiwan University (Lee et al., 1997). The analytical uncertainties are generally better than $5 \%$ for all elements. Loss on ignition was determined by routine procedures. Trace elements were measured by inductively coupled plasma-mass spectrometry (ICP-MS) using a Perkin Elmer ${ }^{\circledR}$ Elan-6000 spectrometer at Guangzhou Institute of Geochemistry, the Chinese Academy of Sciences, which has a good stability range within $\sim 5 \%$ variation. Detailed analytical procedures were reported by Liu et al. (1996) and $\mathrm{Li}$ (1997). Sr and $\mathrm{Nd}$ isotope ratios were measured using VG354 ${ }^{\circledR}$ and Finigan MAT $262{ }^{\circledR}$ mass spectrometers, respectively, at the Institute of Earth Sciences, Academia Sinica, Taipei. Chemical and mass spectrometric procedures were described by Chen et al. (1990). The isotopic ratios were corrected for mass fractionation by normalizing to ${ }^{86} \mathrm{Sr} /{ }^{88} \mathrm{Sr}$ $=0.1194$ and ${ }^{146} \mathrm{Nd} /{ }^{144} \mathrm{Nd}=0.7219$. Long-term laboratory measurements for SRM $987 \mathrm{Sr}$ and $\mathrm{La}$ Jolla (UCSD) Nd standards yield $0.71024 \pm 0.00004$ $(2 \sigma)$ and $0.51187 \pm 0.00003(2 \sigma)$, respectively. All analytical results are listed in Table 1.

Some of the Mienhuayu samples have uncommonly high phosphorus contents, i.e., up to 2-3 wt.\% (MHY-4 and MHY-5). Therefore, rock chips of four samples (MHY-1, MHY-4, MHY-5 and MHY-7) were leached using $1 \mathrm{~N} \mathrm{HCl}$, at $\sim 90{ }^{\circ} \mathrm{C}$, for $20 \mathrm{~min}$. The leached chips were then powdered for major element and $\mathrm{Sr}$ isotope determinations. The leachates were also collected for $\mathrm{Sr}$ isotope determination. Experimental results of the four leached sam- ples are given in Table 2, together with the compositions of unleached samples for comparison.

\section{Whole-rock results}

\subsection{Major elements}

Pre-leached Mienhuayu volcanic rocks show a large variation in their $\mathrm{P}_{2} \mathrm{O}_{5}$ contents $(0.13-3.41$ wt.\%; Table 1). MHY-4 and MHY-5, two samples collected from the top sequence of the lava flows, have the highest $\mathrm{P}_{2} \mathrm{O}_{5}(3.4$ and $2.1 \mathrm{wt} . \%)$ but the lowest $\mathrm{SiO}_{2}$ (49.4 and 50.0 wt.\%) contents. After acid treatment, however, all the four samples show a significant decrease in their $\mathrm{P}_{2} \mathrm{O}_{5}$ contents, and their $\mathrm{SiO}_{2}$ contents increase to $\sim 54$ wt. $\%$ on a volatilefree basis (Table 2). Therefore, this "P-enriched" feature is not primary but due to secondary addition of a high $\mathrm{P}_{2} \mathrm{O}_{5}$ component. Despite the large variation in $\mathrm{P}_{2} \mathrm{O}_{5}$ contents and apparent $\mathrm{P}_{2} \mathrm{O}_{5}$ elevation in certain samples, other major elements do not change significantly (Table 2). Based on the acid leaching experiments, we conclude that the Mienhuayu magmas have a rather uniform composition, with $\mathrm{SiO}_{2}$ content of $\sim 53.5-54.5$ wt. $\%$ and $\mathrm{P}_{2} \mathrm{O}_{5}$ of $\sim 0.1$ wt.\%.

These basaltic andesites plot in the subalkaline or tholeiite field in the total alkalis vs. $\mathrm{SiO}_{2}$ diagram (Fig. 4a), and in the low-K tholeiite field in the $\mathrm{K}_{2} \mathrm{O}$ vs. $\mathrm{SiO}_{2}$ diagram (Fig. 4b). In terms of $\mathrm{SiO}_{2}$ content, they have relatively high $\mathrm{MgO}$ (5.9-8.1 wt.\%), yielding $\mathrm{Mg}$ values of $0.56-0.62$ that are consistent with the high-Mg nature of their phenocryst phases. In comparison with the rest of the NTVZ volcanics, 
Table 2

Comparison for compositions of pre-leached and leached samples

\begin{tabular}{|c|c|c|c|c|c|c|c|c|c|c|c|c|c|c|c|c|}
\hline & $\mathrm{MHY}-1^{\mathrm{a}}$ & $\begin{array}{l}\text { MHY- } \\
1 \mathrm{~L}^{\mathrm{b}}\end{array}$ & $\begin{array}{l}\text { MHY- } \\
1 L_{N}^{c}\end{array}$ & $\begin{array}{l}\text { Var. } \\
(\%)^{\mathrm{d}}\end{array}$ & MHY-4 & MHY-4L & $\begin{array}{l}\text { MHY- } \\
4 L_{N}\end{array}$ & $\begin{array}{l}\text { Var. } \\
(\%)\end{array}$ & MHY-5 & MHY-5L & $\begin{array}{l}\text { MHY- } \\
5 L_{N}\end{array}$ & $\begin{array}{l}\text { Var. } \\
(\%)\end{array}$ & MHY-7 & MHY-7L & $\begin{array}{l}\text { MHY- } \\
7 L_{N}\end{array}$ & $\begin{array}{l}\text { Var. } \\
(\%)\end{array}$ \\
\hline $\mathrm{SiO}_{2}$ & 53.30 & 53.49 & 54.28 & 2 & 49.44 & 51.60 & 54.16 & 8 & 49.99 & 52.25 & 54.33 & 7 & 53.41 & 54.62 & 54.40 & 1 \\
\hline $\mathrm{TiO}_{2}$ & 1.56 & 1.52 & 1.54 & -1 & 1.68 & 1.67 & 1.75 & 3 & 1.61 & 1.59 & 1.65 & 1 & 1.53 & 1.54 & 1.53 & 0 \\
\hline $\mathrm{Al}_{2} \mathrm{O}_{3}$ & 14.52 & 14.14 & 14.35 & -1 & 14.26 & 12.85 & 13.49 & -6 & 14.81 & 13.83 & 14.38 & -4 & 14.35 & 14.45 & 14.39 & 0 \\
\hline $\mathrm{tFe}_{2} \mathrm{O}_{3}$ & 10.79 & 10.51 & 10.66 & -1 & 11.46 & 11.20 & 11.75 & 2 & 11.10 & 10.48 & 10.90 & -3 & 10.58 & 10.61 & 10.57 & -1 \\
\hline $\mathrm{MnO}$ & 0.14 & 0.14 & 0.14 & -1 & 0.13 & 0.14 & 0.14 & 13 & 0.13 & 0.13 & 0.14 & 6 & 0.13 & 0.14 & 0.14 & 3 \\
\hline $\mathrm{MgO}$ & 7.80 & 7.65 & 7.76 & 0 & 6.46 & 6.81 & 7.15 & 10 & 6.69 & 6.62 & 6.88 & 2 & 7.82 & 7.73 & 7.70 & -2 \\
\hline $\mathrm{CaO}$ & 8.22 & 8.06 & 8.18 & 0 & 7.28 & 7.31 & 7.67 & 4 & 7.91 & 8.01 & 8.33 & 4 & 8.22 & 8.20 & 8.16 & -1 \\
\hline $\mathrm{Na}_{2} \mathrm{O}$ & 2.47 & 2.44 & 2.47 & 0 & 2.47 & 2.26 & 2.37 & -5 & 2.53 & 2.47 & 2.57 & 1 & 2.67 & 2.61 & 2.59 & -3 \\
\hline $\mathrm{K}_{2} \mathrm{O}$ & 0.41 & 0.40 & 0.40 & 0 & 0.55 & 0.45 & 0.47 & -16 & 0.45 & 0.43 & 0.44 & -2 & 0.43 & 0.41 & 0.41 & -5 \\
\hline $\mathrm{P}_{2} \mathrm{O}_{5}$ & 0.54 & 0.20 & 0.20 & -62 & 3.41 & 0.99 & 1.04 & -70 & 2.06 & 0.37 & 0.38 & -82 & 0.14 & 0.08 & 0.08 & -46 \\
\hline Total & 100.22 & 98.55 & 100.00 & & 99.02 & 95.28 & 100.00 & & 98.87 & 96.18 & 100.00 & & 99.27 & 100.40 & 100.00 & \\
\hline $\begin{array}{l}{ }^{87} \mathrm{Sr} /{ }^{86} \mathrm{Sr} \\
{ }^{87} \mathrm{Sr} /{ }^{86} \mathrm{Sr}^{\mathrm{e}}\end{array}$ & & $\begin{array}{l}0.70448 \\
0.70910\end{array}$ & & & 0.70722 & $\begin{array}{l}0.70543 \\
0.70914\end{array}$ & & -0.25240 & & $\begin{array}{l}0.70451 \\
0.70902\end{array}$ & & & 0.70438 & $\begin{array}{l}0.70435 \\
0.70902\end{array}$ & & -0.00426 \\
\hline
\end{tabular}

${ }^{\mathrm{a}}$ Values measured before acid leaching.

${ }^{\mathrm{b}}$ Values measured after acid leaching.

${ }^{c}$ Volatile-free recalculated values of the leached samples.

${ }^{\mathrm{d}}$ Var. $(\%)$ : Variation $=\left\{\left([\text { leached sample }]_{\mathrm{N}}-[\text { unleached sample }]_{\mathrm{N}}\right) /[\text { unleached sample }]_{\mathrm{N}}\right\} \times 100 \%$; [sample $]_{\mathrm{N}}$ : volatile-free recalculated values.

${ }^{\mathrm{e}} \mathrm{Sr}$ isotope ratios of the leachates. 
a

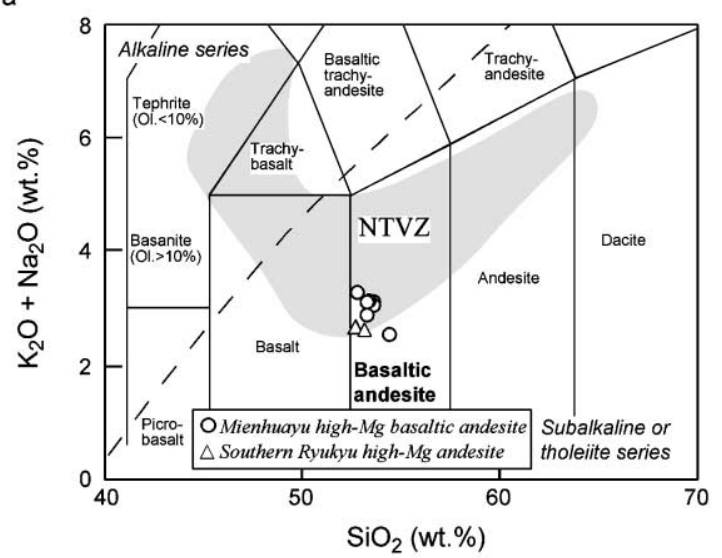

b

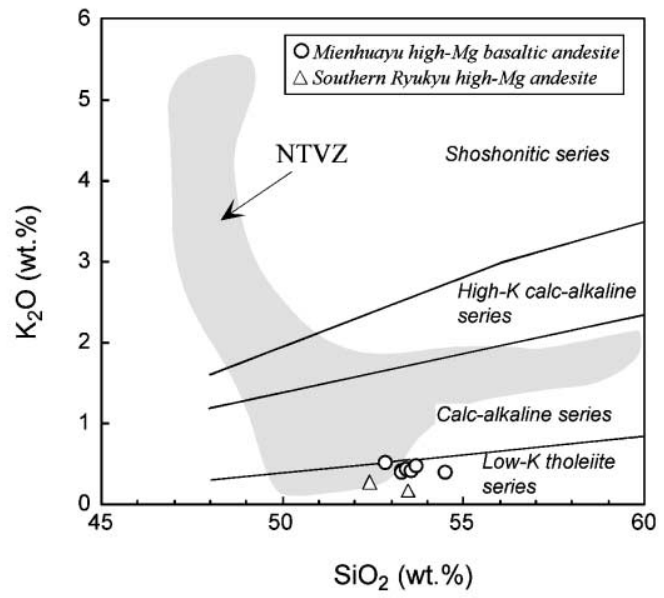

Fig. 4. (a) Total alkalis vs. $\mathrm{SiO}_{2}$ and (b) $\mathrm{K}_{2} \mathrm{O}$ vs. $\mathrm{SiO}_{2}$ of the Mienhuayu lavas, showing their basaltic andesite and low-K tholeiitic natures. Data of the high-Mg andesites from southern Ryukyus (Shinjo, 1999) and compositional range of the NTVZ magmas (Wang et al., 1999; shaded areas) are shown in both diagrams for comparison. Rock type boundaries are from Le Maitre et al. (1989) in (a) and Rickwood (1989) in (b), respectively.

the Mienhuayu high-Mg basaltic andesites have similar $\mathrm{Al}_{2} \mathrm{O}_{3}(\approx 13.5-15.0$ wt. $\%), \mathrm{CaO}(\approx 7.7-8.5$ wt. $\%)$ and $\mathrm{tFe}_{2} \mathrm{O}_{3}(\approx 10.2-11.8$ wt.\%), but higher $\mathrm{TiO}_{2}(\approx 1.4-1.8$ wt.\% $)$ contents.

\subsection{Trace elements}

The Mienhuayu high-Mg basaltic andesites are generally homogeneous in their trace element compositions. In the primitive mantle-normalized incompatible element variation diagram (Fig. 5a), they show smooth distribution patterns with moderate enrichments in LILE and an apparent positive spike in $\mathrm{Pb}$, but are not depleted in HFSE. In comparison with other NTVZ volcanics that show significant HFSE depletion (Wang et al., 1999), the Mienhuayu lavas exhibit less enrichment in LILE (e.g., Cs, Rb, $\mathrm{Ba}, \mathrm{U}$ and $\mathrm{Th}$ ) and $\mathrm{Pb}$ (Fig. 5a), and a less fractionated REE pattern (Fig. 6a). Except for sample MHY2-2, all others show slight enrichment in LREE and a gradual slope change from LREE to MREE (Fig. 6a), which leads to a "kink" REE pattern. This unique feature is similar to that observed in midMiocene high-Mg andesites from the Iriomote-jima, southern Ryukyus (Shinjo, 1999; Fig. 6b). In comparison with high-Mg melts formed in the arc setting, the Mienhuayu lavas have higher trace element abundance than boninites, but a less fractionated variation pattern than adakites (Figs. 5c and 6c).

\subsection{Nd and $\mathrm{Sr}$ isotope ratios}

The Mienhuayu high-Mg basaltic andesites have uniform $\mathrm{Sr}$ and $\mathrm{Nd}$ isotope ratios, with ${ }^{87} \mathrm{Sr} /{ }^{86} \mathrm{Sr} \approx$ $0.70435-0.70543$ (leached values) and ${ }^{143} \mathrm{Nd} /{ }^{144} \mathrm{Nd}$ $\approx 0.51290-0.51301$ (Table 1, Fig. 7). Before the acid-leaching, MHY-4, the sample with extraordinary high $\mathrm{P}_{2} \mathrm{O}_{5}$ content (3.4 wt.\%), shows the highest $\mathrm{Sr}$ isotope ratio $\left({ }^{87} \mathrm{Sr} /{ }^{86} \mathrm{Sr}=0.70722\right.$; Table 1) among the Mienhuayu lavas. However, the leaching experiment indicates that this ratio can be significantly reduced to 0.70543 (Table 2). The sample with the lowest $\mathrm{P}_{2} \mathrm{O}_{5}$ (MHY-7), on the other hand, shows little variation between unleached and leached samples, from 0.70438 to 0.70435 (Table 2). Moreover, $\mathrm{Sr}$ isotope ratios of the leachates from all four

Fig. 5. Primitive mantle-normalized variation diagram for the Mienhuayu high-Mg basaltic andesites. Normalizing values are from Sun and McDonough (1989). Comparing examples shown include: (a) NTVZ volcanics (Wang et al., 1999), (b) Miocene intraplate basalts in NW Taiwan (Chung et al., 1994, 1995) and high-Mg andesites in Iriomote-jima, southern Ryukyus (IR-HMA; Shinjo, 1999), (c) boninite (Cameron et al., 1983), adakites (Kay, 1978; Defant et al., 1991; Kay et al., 1993; Yogodzinski et al., 1995; Stern and Kilian, 1996) and E-MORB (Sun and McDonough, 1989). 

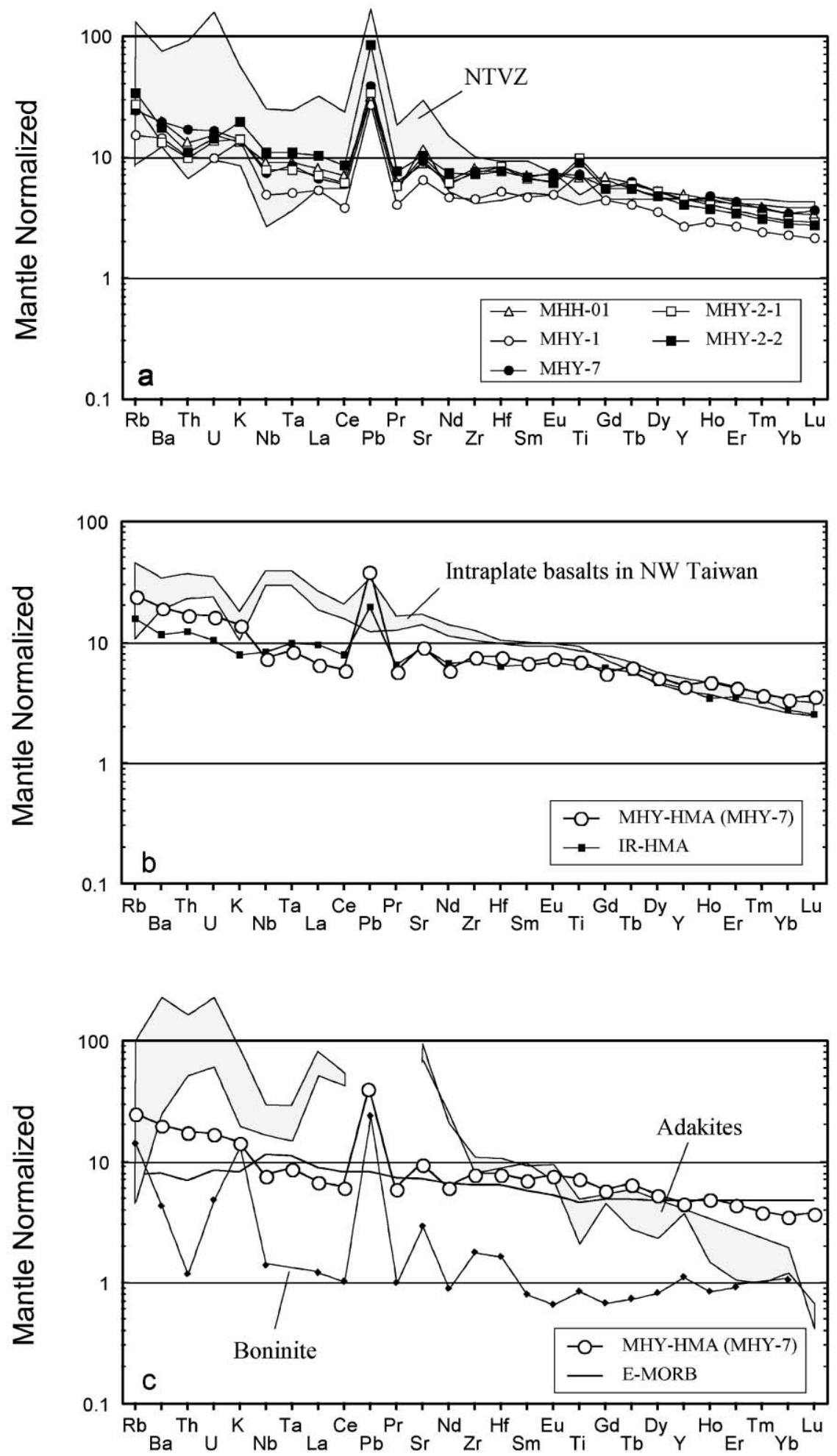

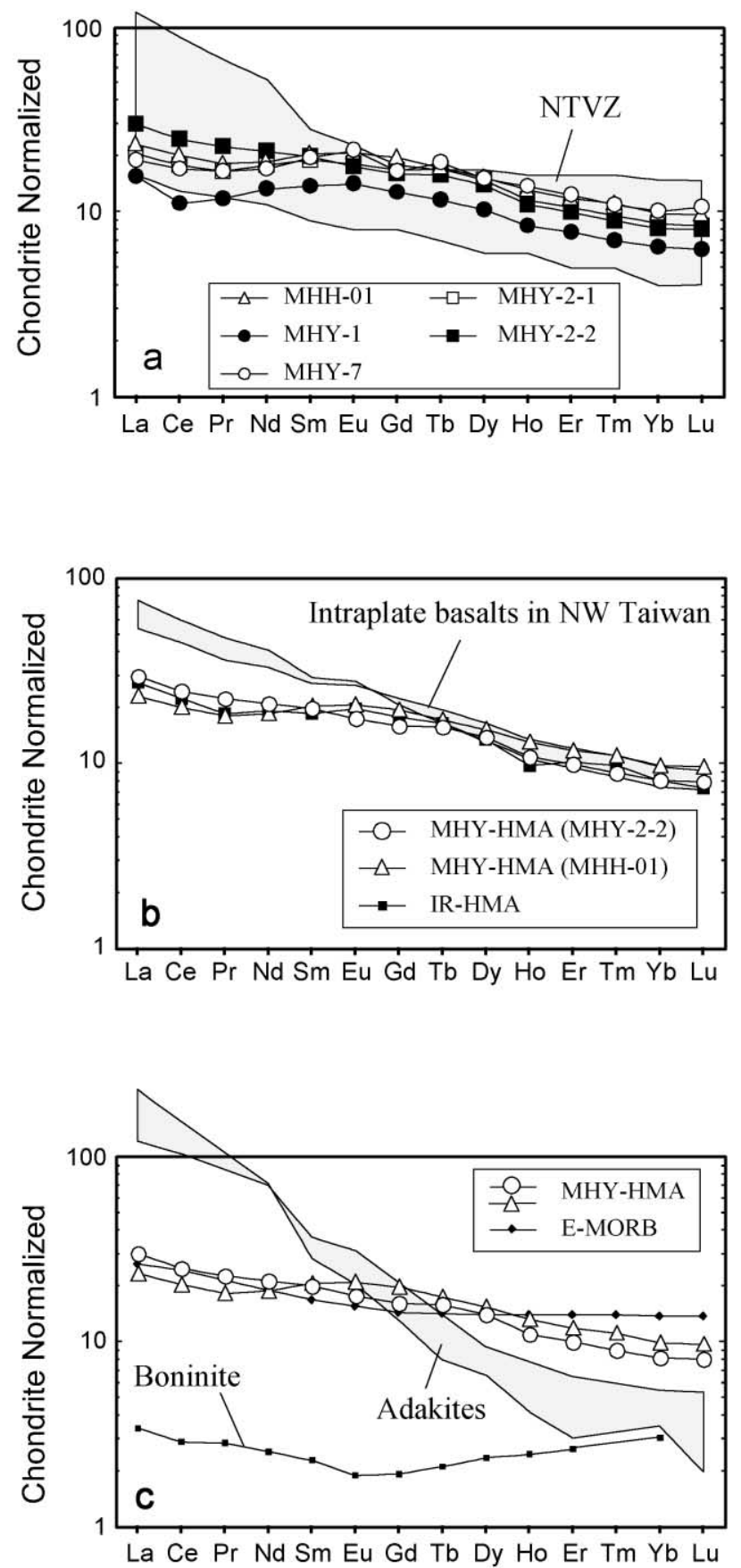

Fig. 6. Chondrite-normalized REE patterns for the Mienhuayu high-Mg basaltic andesites. Data sources are the same as in Fig. 5. Chondrite normalizing values are from Sun and McDonough (1989).

samples are nearly constant $\left({ }^{87} \mathrm{Sr} /{ }^{86} \mathrm{Sr} \approx 0.70902-\right.$ 0.70914; Table 2), which is close to that of the average modern seawater $\left({ }^{87} \mathrm{Sr} /{ }^{86} \mathrm{Sr} \approx 0.70923\right.$; De-
Paolo and Ingram, 1985). These suggest a secondary increase in $\mathrm{Sr}$ isotope ratios of the Mienhuayu magmas associated with the phosphorous addition. Inter- 


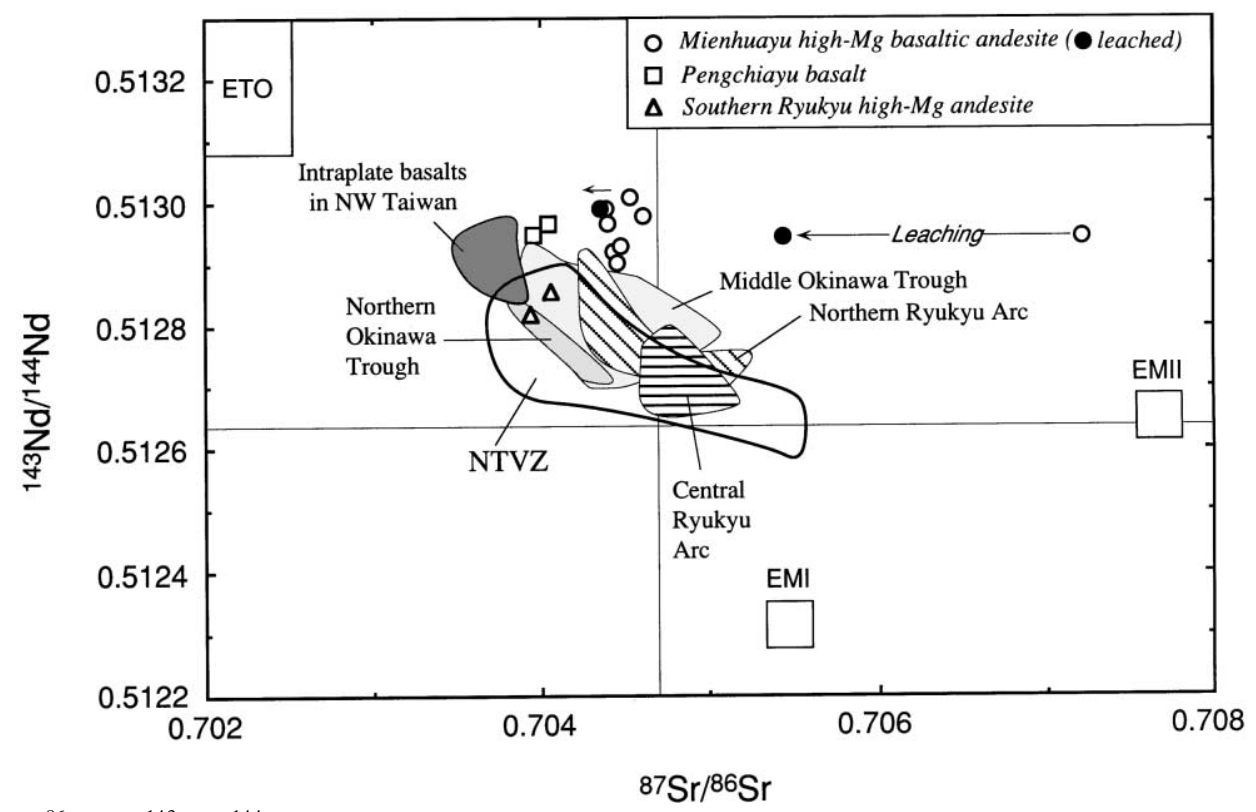

Fig. 7. The ${ }^{87} \mathrm{Sr} /{ }^{86} \mathrm{Sr}$ vs. ${ }^{143} \mathrm{Nd} /{ }^{144} \mathrm{Nd}$ diagram for the Mienhuayu high-Mg basaltic andesites. Data of the Miocene high-Mg andesites from southern Ryukyus are shown for comparison (Shinjo, 1999). Fields for the NTVZ volcanics including the Pengchiayu basalts (Wang et al., 1999), Miocene intraplate basalts from NW Taiwan (Chung et al., 1994, 1995), back-arc basalts from middle Okinawa Trough (Wang, 1998; Shinjo et al., 1999), and volcanics from central and northern Ryukyu Arc (Shinjo et al., 1999, 2000) are also shown. Field of the East Taiwan Ophiolite (ETO) is from Jahn (1986), Chung and Sun (1992). The enriched mantle components of EMI and EMII are from Hart (1988).

estingly, the leached $\mathrm{Sr}$ isotope values are still higher in comparison with their $\mathrm{Nd}$ isotope ratios so that the results plot to the right of the mantle array in the $\mathrm{Nd} / \mathrm{Sr}$ isotopic correlation diagram (Fig. 7).

\section{Discussion}

\subsection{The "excess" $P$ and Sr isotope values}

Some Mienhuayu samples show unusually high phosphorous contents coupled with high $\mathrm{Sr}$ isotope ratios that, as shown in Table 2, can be reduced by acid treatment. Whereas degrees of the reduction are variable $\left(\mathrm{P}_{2} \mathrm{O}_{5} \approx 0.08-1.04\right.$ wt. $\%,{ }^{87} \mathrm{Sr} /{ }^{86} \mathrm{Sr} \approx$ 0.70435-0.70543), all the leachates display nearly identical $\mathrm{Sr}$ isotope ratios $\left({ }^{87} \mathrm{Sr} /{ }^{86} \mathrm{Sr} \approx 0.70902-\right.$ 0.70914 ) which may be explained by seawater alteration. However, the associated "excess" $\mathrm{P}$ feature precludes this explanation. Contamination by biogenic phosphates from marine organisms can ac- count for the high $\mathrm{P}$ and seawater-like $\mathrm{Sr}$ isotope ratios (Staudigel et al., 1985; Ingram et al., 1994; Barrat et al., 2000). However, the Mienhuayu magmas occurred subaerially at $\sim 2.6 \mathrm{Ma}$, and since then sea level has never risen sufficiently to submerge the islet (Naish and Kamp, 1997). Alternatively, biogenic phosphates from terrestrial organisms that may have $\mathrm{Sr}$ isotope ratios higher than that of seawater (Barrat et al., 2000) are the most likely source. The secondary $\mathrm{P}$ and $\mathrm{Sr}$ isotope values could have been added from the source existing as an authigenic phase or simply absorbed onto the surface of the volcanic rocks. This interpretation is consistent with the fact that the samples (e.g., MHY-4, MHY-5) with high $\mathrm{P}$ content and $\mathrm{Sr}$ isotope ratios occurred near the surface of the upper lava sequence, in contrast to those having low $\mathrm{P}_{2} \mathrm{O}_{5}$ content and low ${ }^{87} \mathrm{Sr} /{ }^{86} \mathrm{Sr}$ which occur in the lower volcanic successions (e.g., sample MHY-7). In addition, the upper volcanic sequence is composed of vesicle-rich lavas, whereas the lower part is more compact. Therefore, 
we conclude that the extraordinarily high phosphorous contents and $\mathrm{Sr}$ isotope ratios are derived from terrestrial biogenic phosphates, e.g., guano, that might have coated on the vesicle surface. This secondary addition can be removed by appropriate acid treatment.

The leached Mienhuayu volcanic rocks still show elevated $\mathrm{Sr}$ isotope ratios relative to the associated $\mathrm{Nd}$ isotope ratios (Fig. 7). Three causes may account for this feature: (1) the leaching experiments did not completely remove the secondary addition; (2) some degrees of the secondary alteration cannot be removed by the acid leaching; and (3) the elevation of $\mathrm{Sr}$ isotope ratios is a real feature of the Mienhuayu magmas. The first possibility may be applied to sample MHY-4 whose leached phosphorous content is high $\left(\mathrm{P}_{2} \mathrm{O}_{5}=1.03\right.$ wt.\%; Table 2). However, with leached phosphorous content as low as $0.08 \mathrm{wt} \%$, sample MHY-7 still has a higher than expected $\mathrm{Sr}$ isotope ratio which decreases only from ${ }^{87} \mathrm{Sr} /{ }^{86} \mathrm{Sr}=$ 0.70438 (unleached) to ${ }^{87} \mathrm{Sr} /{ }^{86} \mathrm{Sr}=0.70435$ (leached). In addition, the leachate of sample MHY-7 yielded $\mathrm{Sr}$ isotope ratio $\left({ }^{87} \mathrm{Sr} /{ }^{86} \mathrm{Sr}=0.70902\right)$ indistinguishable from leachates of the other three samples (Table 2). Thus, we believe that in this sample the alteration effect for $\mathrm{P}_{2} \mathrm{O}_{5}$ content and $\mathrm{Sr}$ isotope ratio has been totally removed by leaching. In this sense, the first and second possibilities are less likely, or at least insignificant, for the elevated $\mathrm{Sr}$ isotope ratio of leached MHY-7 that plots to the right of the mantle isotopic array (Fig. 7). It is hence implied that the mantle source of the Mienhuayu magmas is characterized by higher $\mathrm{Sr}$ isotope ratios relative to associated $\mathrm{Nd}$ isotope ratios.

Such an elevation of $\mathrm{Sr}$ isotope ratios in the mantle source may be ascribed to the nearby Ryukyu subduction zone processes. As discussed by Tatsumi and Eggins (1995), convergent-margin magmas often show across-arc isotopic variations, with high $\mathrm{Sr}$ isotope ratios in the trench side, that can be explained by interactions between the mantle wedge and subduction components (e.g., subducted sediments or fluids). The Mienhuayu magmas, however, do not display this kind of co-variation with the rest of NTVZ volcanics. According to our recently obtained $\mathrm{Pb}$ isotope data (Wang et al., unpubl.), the Mienhuayu rocks have nearly identical leached and unleached values $\left({ }^{206} \mathrm{~Pb} /{ }^{204} \mathrm{~Pb}=18.577-18.602\right.$,
${ }^{207} \mathrm{~Pb} /{ }^{204} \mathrm{~Pb}=15.599-15.611, \quad{ }^{208} \mathrm{~Pb} /{ }^{204} \mathrm{~Pb}=$ 38.729-38.767) marking with a DUPAL-type $\mathrm{Pb}$ isotope anomaly. Similar $\mathrm{Pb}$ isotope signatures have been reported in the Miocene intraplate basalts around NW Taiwan (Chung et al., 1994, 1995) and the Quaternary arc volcanics from northern Ryukyus (Shinjo et al., 2000). It is widely recognized that a DUPAL-like asthenospheric domain, or an Indian Ocean type convecting mantle, underlies the entire East Asian continent and marginal basins in the western Pacific (Flower et al., 1998; Smith, 1998; Chung et al., 2001a). A typical DUPAL mantle component, following the original definition by Hart (1984), is commonly associated with high $\mathrm{Sr}$ isotope ratios. We therefore speculate the elevated $\mathrm{Sr}$ isotope ratios observed in the Mienhuayu magmas to be derived from an asthenospheric mantle source with such isotopic features.

\subsection{Petrogenesis of the Mienhuayu high-Mg basaltic andesites}

High-Mg andesites are commonly observed in two tectonic environments, i.e., in the fore-arc regions of convergent margins, and intraplate rifts (Crawford et al., 1989). The Mienhuayu high-Mg basaltic andesites were emplaced in the back-arc region, distant from the Ryukyu fore-arc. The lavas are rich in the "basaltic component", with $\mathrm{CaO} \approx$ 7.7-8.5 wt. $\%, \mathrm{tFe}_{2} \mathrm{O}_{3} \approx 10.2-11.8$ wt. $\%$ and $\mathrm{TiO}_{2}$ $\approx 1.4-1.8 \mathrm{wt} . \%$, reflecting a fertile mantle source. Their incompatible element contents are apparently higher and show different variation pattern (Figs. 5c and $6 \mathrm{c}$ ) from those of boninites. Thus, a fore-arc origin is considered unlikely.

The Mienhuayu volcanics have geochemical features distinctive from the other NTVZ volcanics (cf. Wang et al., 1999). The latter generally have a calc-alkaline nature similar to that observed in convergent-margin magmas (Gill, 1981). In terms of incompatible elements the Mienhuayu volcanics display less enrichments in LILE and Pb (Fig. 5a) and lack the distinctive HFSE depletion shown by typical subduction-related magmas (McCulloch and Gamble, 1991). They also show the highest $\mathrm{Nd}$ isotopic ratios among the NTVZ volcanics (Fig. 7), virtually similar to those of Miocene ( 23-9 Ma) intraplate basalts from NW Taiwan (Chung et al., 1994, 1995), and 

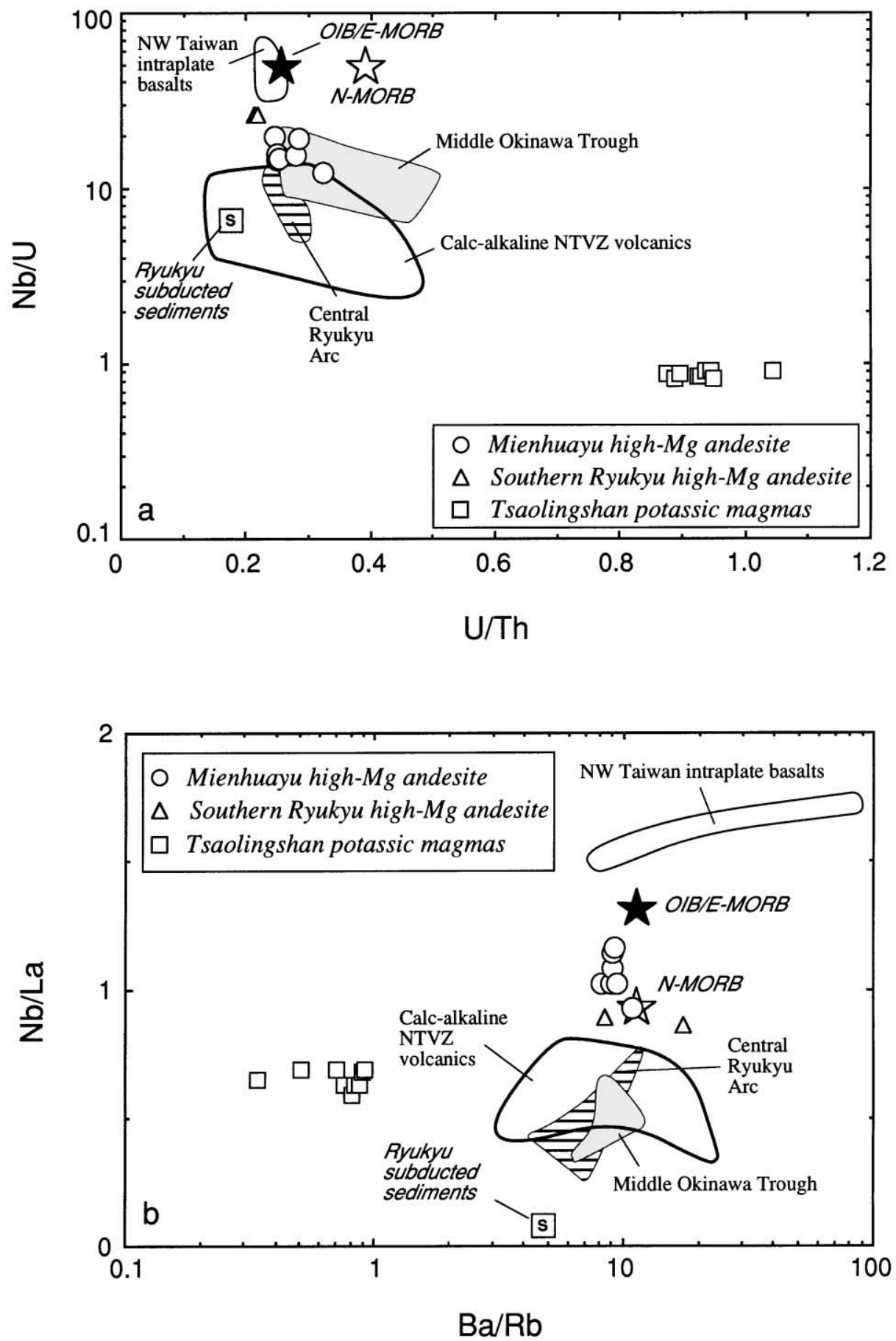

Fig. 8. Plots of (a) Nb/U vs. U/Th and (b) Nb/La vs. Rb/Ba ratios for the Mienhuayu high-Mg basaltic andesites. Values of N-MORB, E-MORB and OIB are from Sun and McDonough (1989), the Ryukyu subducted sediments are from Plank and Langmuir (1998). Fields for the NTVZ volcanics, NW Taiwan intraplate basalts, and magmas from central Ryukyu Arc and middle Okinawa Trough are according to Wang et al. (1999), Chung et al. (1994, 1995) and Shinjo et al. (1999), respectively. 
higher than those of the high-Mg andesites from southern Ryukyus (Shinjo, 1999). Their high Nd isotope ratios ( $\varepsilon \mathrm{Nd}$ up to +7.2 ) suggest an asthenospheric mantle source. Moreover, the Mienhuayu volcanics show similar, though lower in LILE and LREE abundance, incompatible element variation pattern to those of the NW Taiwan intraplate basalts and almost the same pattern as the southern Ryukyus high-Mg andesites (Figs. 5b and 6b). It is important to note that the latter two magma suites resulted from decompressional asthenospheric melting owing to intraplate lithospheric extension and attenuation that took place prior to the arc-continent collision in Taiwan (Chung et al., 1994, 1995; Shinjo, 1999).

The intraplate geochemical affinities of the Mienhuayu volcanics are clearly illustrated in a $\mathrm{Nb} / \mathrm{U}$ vs. $\mathrm{U} /$ Th plot (Fig. 8a). Among the NTVZ volcanics, the Mienhuayu rocks have the highest $\mathrm{Nb} / \mathrm{U}$ ratios $(\approx 20)$ that plot close to southern Ryukyus high-Mg andesites, NW Taiwan intraplate basalts and the average values of OIB and E-MORB. The EMORB/OIB affinity is also shown in a $\mathrm{Nb} / \mathrm{La}$ vs. $\mathrm{Ba} / \mathrm{Rb}$ plot (Fig. 8b), which is consistent with the unradiogenic $\mathrm{Nd}$ isotopic ratios of the Mienhuayu lavas. Therefore, we propose that the Mienhuayu high-Mg basaltic andesites are silica-saturated melts that originated from ascending asthenospheric mantle having a composition similar to that of E-MORB. Such an asthenospheric mantle, however, may have been subtly affected by the Ryukyu subduction zone processes that account for the positive $\mathrm{Pb}$ spike.

Kushiro (1969) reported that primary silicasaturated melts can be produced by partial melting of mantle peridotites (1) at shallow depths (i.e., $<7 \mathrm{~kb}$ or $\sim 20 \mathrm{~km}$ ) under anhydrous condition or (2) deeper (e.g., down to $60-70 \mathrm{~km}$ or $20 \mathrm{~kb}$ ) under hydrous condition. Given that the continental crust is $\sim 30$ $\mathrm{km}$ thick beneath northern Taiwan (Yeh et al., 1989), the anhydrous melting scenario is unlikely for generation of the Mienhuayu high-Mg basaltic andesites. Thus, the parental magmas for Mienhuayu volcano must have originated from deeper depths, which we suggest to have been the asthenospheric mantle under hydrous conditions. The depth of magma segregation may be constrained via certain trace element signatures. The Mienhuayu volcanics have low HREE and $\mathrm{Y}$, implying residual garnet in the mantle source. Their $\mathrm{La} / \mathrm{Yb}(\approx 2-3)$ and $\mathrm{Sr} / \mathrm{Y}(\approx 9.6-11)$ ratios are lower than those of magmas marked by garnet fractionation (e.g., adakite: $\mathrm{La} / \mathrm{Yb}>20, \mathrm{Sr} / \mathrm{Y}>40$; Defant and Drummond, 1990; Figs. 5c and 6c). It is therefore suggested that the mantle source of the Mienhuayu lavas, is not as deep as adakites and perhaps located near the upper limit of the garnet stability field. In other words, the mantle source resides at $60-70 \mathrm{~km}$ depth, around the transition zone between spinel and garnet stability fields (Wyllie, 1981). The required hydrous condition can be obtained by dehydration of the subducting Philippine Sea plate in adjacent Ryukyu subduction zone. This subduction-related modification, however, is "subtle" because the Mienhuayu rocks show only moderate enrichments in LILE and $\mathrm{Pb}$.

The REE "kink" observed in the Mienhuayu volcanics needs an explanation. Unlike typical boninites whose REE patterns are V-shaped (Fig. 6c), the Mienhuayu lavas have a gradual slope change from LREE to MREE (Fig. 6) and thus show the "kink" feature. In comparison with E-MORB, they show a similar pattern of slight enrichment LREE, but lower HREE abundance (Fig. 6c). The LREE enrichment, however, is apparently lower than that revealed by the NW Taiwan intraplate tholeiitic basalts (Fig. 6b). Melt-wall rock interaction may occur during magma ascent (cf. Kelemen, 1990) and this interaction could reduce LREE contents relative to HREE in the ascending magmas (Kelemen et al., 1993). Following the interpretation by Shinjo (1999) for a similar "kink" REE feature observed in the southern Ryukyus high-Mg andesites, we also adopt the melt-mantle interaction model to account for the REE pattern of the Mienhuayu volcanics.

\section{Concluding remarks}

The Mienhuayu islet, formed mainly by subaerial effusion at about 2.6 Ma, is composed of basaltic andesite lavas and subordinate scoria deposits. These rocks show high-Mg characters that may represent silica-saturated melts derived from a shallow mantle source. Compared with other NTVZ volcanics, the Mienhuayu high-Mg basaltic andesites exhibit distinct geochemical features without HFSE depletion. Their overall geochemical affinities are similar to Miocene intraplate basalts from NW Taiwan and 
high-Mg andesites from the southern Ryukyus. Such similarities allow us to conclude that the Mienhuayu magmas were derived from an E-MORB type, ascended asthenospheric mantle as a result of extensional collapse of the northern Taiwan mountain belt at the Plio-Pleistocene boundary. Eruption of the Mienhuayu lavas supports the notion that a substantial lithospheric extensional regime occurred before, and thus probably accounts for, the southwestward propagation of the Okinawa Trough.

\section{Acknowledgements}

We thank C.Y. Lee and X.H. Li for their help in arranging XRF and ICP-MS analysis, and F.T. Yang, C.H. Lo and Y.G. Chen for helpful discussion. We are most grateful for the detailed and constructive reviews provided by I. Graham, J. Gamble and journal editor R. Rudnick, which significantly improved the content and presentation of this paper. This study benefited from financial support of the National Science Council and Institute of Earth Sciences, Academia Sinica, Taiwan.

\section{References}

Barrat, J.A., Taylor, R.N., Andre, J.P., Nesbitt, R.W., Lecuyer, Ch., 2000. Strontium isotopes in biogenic phosphates from a Neogene marine formation: implications for palaeoseawater studies. Chem. Geol. 168, 325-332.

Cameron, W.E., McCulloch, M.T., Walker, D.A., 1983. Boninite petrogenesis: chemical and $\mathrm{Nd}-\mathrm{Sr}$ isotopic constraints. Earth Planet. Sci. Lett. 65, 75-89.

Chen, C.-H., 1990. Igneous Rocks of Taiwan. Central Geological Survey, Taiwan (in Chinese).

Chen, C.H., 1997. Comment to "Extensional collapse of the northern Taiwan mountain belt". Geology 25, 855.

Chen, C.H., Shieh, Y.N., Lee, T., Chen, C.H., Mertzman, S.A., 1990. Nd-Sr-O isotopic evidence for source contamination and unusual mantle component under Luzon Arc. Geochim. Cosmochim. Acta 54, 2473-2484.

Chung, S.L., Sun, S.-S., 1992. A new genetic model for the East Taiwan Ophiolite and its implications for Dupal domain in the northern hemisphere. Earth Planet. Sci. Lett. 109, 133-145.

Chung, S.L., Sun, S.-S., Tu, K., Chen, C.-H., Lee, C.Y., 1994. Late Cenozoic basaltic volcanism around the Taiwan Strait, SE China: product of lithosphere-asthenosphere interaction during continental extension. Chem. Geol. 112, 1-20.

Chung, S.L., Jahn, B.M., Chen, S., Lee, T., Chen, C.-H., 1995. Miocene basalts in northwestern Taiwan: evidence for EM-type mantle sources in the continental lithosphere. Geochim. Cosmochim. Acta 59, 549-555.

Chung, S.L., Sun, S.-S., Crawford, A.J., 2001a. Indian ocean type convecting mantle underlies East Asia: a consequence of Gondwana breakup and reassembly? W. Pac. Earth Sci. 1, $1-18$.

Chung, S.L., Wang, K.L., Crawford, A.J., Kamenetsky, V.S., Chen, C.-H., Lan, C.Y., Chen, C.H., 2001b. Highly magnesian potassic magmas in the arc-continent collision belt of Taiwan: implication for the genesis of orogenic potassic lavas and the slab component of subduction zones. Lithos (in revision).

Crawford, A.J., Falloon, T.J., Green, D.H., 1989. Classification, petrogenesis and tectonic setting of boninites. In: Crawford, A.J. (Ed.), Boninites. Unwin Hyman, London, pp. 1-49.

Defant, M.J., Drummond, M.S., 1990. Derivation of some modern arc magmas by melting of young subducted lithosphere. Nature 347, 662-665.

Defant, M.J., Richerson, P.M., De Boer, J.Z., Stewart, R.H., Maury, R.C., Bellon, H., Drummond, M.S., Feigenson, M.D., Jackson, T.E., 1991. Dacite genesis via slab melting and differentiation: petrogenesis of La Yeguada volcanic complex, Panama. J. Petrol. 32, 1101-1142.

DePaolo, D.J., Ingram, B.L., 1985. High-resolution stratigraphy with Strontium isotopes. Science 227, 938-941.

Flower, M.F.J, Tamaki, K., Hoang, N., 1998. Mantle extrusion: a model for dispersed volcanism and DUPAL-like asthenosphere in East Asia and the western Pacific. In: Flower, M.F.J. (Ed.), Mantle Dynamics and Plate Interactions in East Asia. American Geophysical Union, Washington, DC, pp. 67-88.

Gill, J.B., 1981. Orogenic Andesites and Plate Tectonics. Springer, Berlin.

Hart, S.R., 1984. A large-scale isotope anomaly in the Southern Hemisphere mantle. Nature 309, 753-757.

Hart, S.R., 1988. Heterogeneous mantle domains: signatures, genesis and mixing chronologies. Earth Planet. Sci. Lett. 90, 273-296.

Ingram, B.L., Coccioni, R., Montanari, A., Richter, F.M., 1994. Strontium isotopic composition of mid-Cretaceous seawater. Science 264, 546-550.

Jahn, B.M., 1986. Mid-ocean ridge or marginal basin origin of the East Taiwan Ophiolite: chemical and isotopic evidence. Contrib. Mineral. Petrol. 92, 194-206.

Juang, W.S., 1993. Diversity and origin of Quaternary basaltic magma series in northern Taiwan. Bull. Natl. Mus. Nat. Sci. 4, 125-166.

Kay, R.W., 1978. Aleutian magnesian andesites: melts from subducted Pacific Ocean crust. J. Volcanol. Geotherm. Res. 4, 117-132.

Kay, S.M., Ramos, V.A., Marquez, M., 1993. Evidence in Cerro Pampa volcanic rocks for slab melting prior to ridge-trench collision in southern South America. J. Geol. 101, 703-714.

Kelemen, P.B., 1990. Reaction between ultramafic rock and fractionating basaltic magma: I. Phase relations, the origin of calc-alkaline magma series, and the formation of discordant dunite. J. Petrol. 31, 51-98.

Kelemen, P.B., Shimuzu, N., Dunn, T., 1993. Relative depletion of niobium in some arc magmas and the continental crust: 
partitioning of $\mathrm{K}, \mathrm{Nb}$, $\mathrm{La}$ and $\mathrm{Ce}$ during melt/rock reaction in the upper mantle. Earth Planet. Sci. Lett. 120, 111-134.

Kushiro, I., 1969. The system forsterite-diopside-silica with and without water at high pressures. Am. J. Sci., Sch. 267-A, 269-294.

Lee, C.Y., Tsai, J.H., Ho, H.H., Yang, T.F., Chung, S.L., Chen, C.-H., 1997. Quantitative analysis in rock samples by an X-ray fluorescence spectrometer (I) major elements. Ann. Meeting Geol. Soc. China, Geol. Soc. China, Taipei, pp. 418-420 (in Chinese).

Le Maitre, R.W., Bateman, P., Dudek, A., Keller, J., Lameyre Le Bas, M.J., Sabine, P.A., Schmid, R., Sorensen, H., Streckeisen, A., Woollley, A.R., Zanettin, B., 1989. A Classification of Igneous Rocks and Glossary of Terms. Blackwell, Oxford.

Li, X.H., 1997. Geochemistry of the Longsheng Ophiolite from the southern margin of Yangtze Craton, SE China. Geochem. J. 31, 323-337.

Liu, Y., Liu, H., Li, X.H., 1996. Simultaneous and precise determination of 40 trace elements in rock samples. Geochimica 25, 552-558 (in Chinese).

McCulloch, M.T., Gamble, J.A., 1991. Geochemical and geodynamical constraints on subduction zone magmatism. Earth Planet. Sci. Lett. 102, 358-374.

Naish, T., Kamp, P.J.J., 1997. Sequence stratigraphy of sixth-order (41 k.y.) Pliocene-Pleistocene cyclothems, Wanganui basin, New Zealand: a case for the regressive systems tract. Geol. Soc. Am. Bull. 109, 978-999.

Paulick, H., Franz, G., 1997. The color of pumice: case study on a trachytic fall deposit, Meidob volcanic field, Sudan. Bull. Volcanol. 59, 171-185.

Plank, T., Langmuir, C.H., 1998. The chemical composition of subducting sediment and its consequences of the crust and mantle. Chem. Geol. 145, 325-394.

Rickwood, P.C., 1989. Boundary lines within petrologic diagrams which use oxides of major and minor elements. Lithos 22, 247-263.

Rowland, S.K., Walker, G.P.L., 1990. Pahoehoe and aa in Hawaii: volumetric flow rate controls the lava structure. Bull. Volcanol. 52, 615-628.

Self, S., Keszthelyi, L., Thordarson, T., 1998. The importance of pahoehoe. Annu. Rev. Earth Planet. Sci. 26, 81-110.

Shinjo, R., 1999. Geochemistry of high $\mathrm{Mg}$ andesites reflects the tectonic evolution of the Okinawa Trough-Ryukyu arc system. Chem. Geol. 157, 69-88.

Shinjo, R., Ban, M., Saito, K., Kato, Y., 1991. K-Ar dating of the volcanic rocks in the Ryukyu arc. J. Mineral Petrol. Econ. Geol. 86, 323-328 (in Japanese).

Shinjo, R., Chung, S.L., Kato, Y., Kimura, M., 1999. Geochemical and $\mathrm{Sr}-\mathrm{Nd}$ isotopic characteristics of volcanic rocks from the Okinawa Trough and Ryukyu Arc: implications for the evolution of a young, intracontinental back arc basin. J. Geophys. Res. 104, 10591-10608.

Shinjo, R., Woodhead, J.D., Hergt, J.M., 2000. Geochemical variation within the northern Ryukyu Arc: magma source compositions and geodynamic implications. Contrib. Mineral. Petrol. 140, 263-282.
Sibuet, J.-C., Deffontaines, B., Hsu, S.-K., Thareau, N., Le Formal, J.-P., Liu, C.S., the ACT party, 1998. The Okinawa Trough backarc basin: early tectonic and magmatic evolution. J. Geophys. Res. 103, 30245-30267.

Smith, A.D., 1998. The geodynamic significance of the DUPAL anomaly in Asia. In: Flower, M.F.J. (Ed.), Mantle Dynamics and Plate Interactions in East Asia. American Geophysical Union, Washington, DC, pp. 89-105.

Staudigel, H., Doyle, P., Zindler, A., 1985. Sr and Nd isotope systematics in fish teeth. Earth Planet. Sci. Lett. 76, 45-56.

Stern, C.R., Kilian, R., 1996. Role of the subducted slab, mantle wedge and continental crust in the generation of adakites from the Andean Austral Volcanic Zone. Contrib. Mineral. Petrol. 123, 263-281.

Sun, S.-S., McDonough, W.F., 1989. Chemical and isotopic systematics of oceanic basalts: implications for mantle composition and processes. In: Saunders, A.D., Norry, M.J. (Eds.), Magmatism in the Ocean Basins. Geol. Soc. Spec. Publ., vol. 42. Blackwell Scientific Publications, Melbourne, pp. 313345 .

Tatsumi, Y., Eggins, S., 1995. Subduction Zone Magmatism. Blackwell, Cambridge, MA.

Tatsumi, Y., Maruyama, S., 1989. Boninites and high-Mg andesites: tectonics and petrogenesis. In: Crawford, A.J. (Ed.), Boninites. Unwin Hyman, London, pp. 50-71.

Teng, L.S., 1990. Geotectonic evolution of late Cenozoic arc-continent collision in Taiwan. Tectonophysics 183, 57-76.

Teng, L.S., 1996. Extensional collapse of the northern Taiwan mountain belt. Geology 24, 949-952.

Wang, S.L., 1998. Ar-Ar dating and geochemistry of volcanic rocks dredged from the middle Okinawa Trough. MS thesis, Natl. Taiwan Univ., Taiwan (in Chinese).

Wang, W.S., Chen, C.-H., 1990. The volcanology and fission track age dating of pyroclastic deposits in Tatun Volcano group, northern Taiwan. Acta Geol. Taiwan 28, 1-30.

Wang, K.L., Chung, S.L., Shinjo, R., Chen, C.H., Yang, T.F., Chen, C.-H., 1999. Post-collisional magmatism around northern Taiwan and its relation with opening of the Okinawa Trough. Tectonophysics 308, 363-376.

Wang, K.L., Chen, C.H., Lee, H.Y., Chung, S.L., Lo, C.H., Yang, T.F., 2000. Field occurrence, ${ }^{40} \mathrm{Ar} /{ }^{39} \mathrm{Ar}$ dating and petrochemical features of volcanic rocks in Mienhuayu off NE Taiwan. J. Geol. Soc. China 43, 247-266.

Wyllie, P.J., 1981. Plate tectonics and magma genesis. Geol. Rundsch. 70, 128-153.

Yeh, Y.H., Lin, C.H., Roecker, S.W., 1989. A study of upper crustal structures beneath northeastern Taiwan: possible evidence of the western extension of Okinawa Trough. Proc. Geol. Soc. China 32, 139-156.

Yogodzinski, G.M., Kay, R.W., Volynets, O.N., Koloskov, A.V., Kay, S.M., 1995. Magnesian andesite in the western Aleutian Komandorsky region: implications for slab melting and processes in the mantle wedge. Geol. Soc. Am. Bull. 107, 505519. 